\title{
Using a Faculty Portfolio in the Distinction of Teaching
}

\author{
M. Samaka \\ Department of Computer Science \\ University of Qatar \\ P O Box 2713 \\ Doha, Qatar \\ samaka.m@qu.edu.qa
}

\begin{abstract}
In this paper a faculty portfolio in the computer science discipline is being designed and used in teaching summative evaluation. As an example model, the paper presents an academic portfolio that intends to contain the author's major achievements in teaching at a university level. The portfolio was submitted for the faculty distinction award in teaching at UAE University in United Arab Emirates. The structure of the portfolio was carefully designed according to a suggested evaluation criteria model concluded throughout an investigation study conducted by the author of this paper. The structure also meets the summative rating process for the faculty distinction award in teaching at UAE University.
\end{abstract}

Keywords: Faculty portfolio, teaching portfolio, teaching award, teaching distinction, teaching summative evaluation

\section{Introduction}

In reviewing the literature, several definitions of a teaching portfolio emerge. Some definitions confine the portfolio to a summary of the teacher's accomplishments. In this context, Cerbin (1994) stated, "a teaching portfolio is a coherent set of materials including work samples and reflective commentary on them compiled by a faculty member to represent his or her teaching practice as related to student learning and development". Other definitions are much broader in scope, suggesting that the portfolio as a comprehensive, self-reflective record of a teacher's strengths and weaknesses (Advisory Center for University Education, 1997). It is probable that the best advice for establishing a definition (and thus a framework for content selection) is offered by Murray (1995). He suggested that you should decide how to use the portfolio before contemplating upon the content. If the portfolio is to be used for summative evaluation, such as tenure decisions, then it should only contain the best of a teacher's work. If, however, the portfolio is to be used for formative evaluation, then it should be more comprehensive. Overall, the following definition might tentatively be given for a teaching portfolio: "It is a record that documents your work as a teacher".

Centra (1994), on the other hand, examined the use of portfolios for faculty evaluation at a community college. He found that using portfolios were useful for evaluating teaching performance, especially when combined with student ratings. He also recommended that when using portfolios for evaluation, standard criteria by which they are to be judged should be established. Another study
(Ross, Bondy, Hartle, Lamme, and Webb, 1995) that had five qualitative researchers evaluated the effectiveness of teaching portfolios designed to support claims of excellence made by teachers. In essence, the study was designed to identify characteristics of effective portfolios. Ross, et al. suggested seven guidelines for portfolio development based on the portfolios found to be exceptional in this study.

Every academic year, UAE University recognizes its best teachers in a special fall awards ceremony, where the honorees are officially recognized, and receive an honorarium, a certificate from the university's President. At UAE University, the faculty member's teaching portfolio is normally evaluated at the college to which the faculty is associated. The raters of the portfolios are normally two peer faculty members and the college dean. Every year, the college selects the most highly rated faculty portfolio and nominates it to the university award for teaching excellence. A University Excellence in Teaching Awards Committee will then carefully scrutinize the nominations submitted by the colleges, reviewing the associated student evaluations and other supporting material, and then select only one individual for the University Excellence in Teaching Award.

In this paper, the author intends to present, as an example model, his teaching portfolio that was submitted for the faculty distinction award in teaching at UAE University in United Arab Emirates for the year 2002. This portfolio was structured according to a suggested evaluation criteria model concluded throughout an investigation study conducted by the author of this paper. 
The structure also meets the summative rating process for the faculty distinction award in teaching at UAE University.

The suggested process by which the best teachers are selected is extremely competitive and based upon assessing teaching portfolios. Faculty members to develop their teaching portfolios by documenting their accomplishments in seven areas: (1) Teaching Techniques; (2) Curriculum Development; (3) Relevancy Handouts \& Textbooks; (4) Student Evaluation; (5) Course Portfolio; (6) Offering Short Courses, Conferences, And Workshops For Teaching Development; and (7): Teaching Related Publications.

The teaching portfolio for the author was submitted to the university award committee with the following other items;

(a) Appendices that include the supportive evidence to this portfolio

(b) The author's Curriculum Vitae

(c) The author's career statement

\section{Career Statement}

In this section of the portfolio document, the author introduces his academic experience as a computer scientist that reflects his strong commitments to teaching, research and other academic activities. Throughout the years of his academic career, the author describes his contribution to tutoring and supervising students at undergraduate and postgraduate levels. He then presents his involvement in many other academic activities, in teaching a variety of basic and advanced topics; supervising laboratories; providing technical advice to staff and faculty members; preparing course curricula and contributing to many essential academic and research committees. He also explains how he managed to maintain reasonable contact with research in his area of specialization, which resulted in the publication of several papers in recognized journals and conference proceedings.

Further to that, the author describes here his academic duty at the College of Information Technology (CIT) of the UAE University between the period September 1999, and June 2002. During that time, he was responsible of chairing the Department of Computer Science.

\section{Meeting the Criteria for Teaching Excellence}

The teaching portfolio designed in this paper, as a structure of seven criteria was implemented using the author's portfolio document submitted for the faculty distinction award in teaching at the UAE University in year 2002. This teaching portfolio is introduced in the following sections as an example model of using a faculty portfolio in teaching summative evaluation.

\subsection{Criterion \#1: Teaching Techniques}

Since the time I joined the UAE University on September 1999, I taught several computer science courses, these include Java, $\mathrm{C}^{++}$, Database, Networking, and Operating Systems. I also contributed to student training and supervised over thirty students on their final year.

I consider that teaching is one of the most challenging and most rewarding experiences a person can have. It is my belief that teaching must entwine two qualities: enthusiasm and intellect. I cannot separate the two and use them to guide me through every lecture/lab I embrace. For monitoring both qualities, I normally apply the following teaching techniques:

- In every course, I attempt to follow two principles: create an atmosphere conducive to learning and be fair. To me, creating a good learning atmosphere involves showing respect for individual students, learning the students' names and using them, approaching the course and each session in a positive manner, allowing the students to make choices, and doing my best to model good communication practices. Being fair includes making the evaluation criteria clear and holding all students to those criteria, establishing reasonable expectations that students can meet with effort, and presenting the ideas I expect the students to retain as clearly as I can.

- My office hours are transformed into a space and time for students to meet regularly, discuss the material, discover new ideas, and ask questions as they come up.

- I always attempt to build student ownership into learning, that is, where students take responsibility for their own learning. I believe this is crucial to students becoming creative and independent learners. I believe that we act as a catalyst in the process of learning. We can ignite their interest so learning becomes an enjoyable experience. So, I see myself as a facilitator in the learning process, helping students to gain confidence to internalise concepts and thus apply them to new situations.

- When teaching, the techniques I apply vary according to the level of my students. Whether the students are at the sophomore, junior, or senior level, I normally apply the ratio of instructor direct teaching to student self-learning as; $2: 1,2: 2$, and $1: 2$ on sophomore, junior, and senior student levels respectively. When teaching sophomore students, my task is to teach knowledge and new perspectives for them to apply to their own lives, as well as to build their professional perspectives and skills. When working with junior students, I view my task as helping them define a theoretical perspective and a set of skills for the practical delivery that is consistent with that theoretical orientation. Working with senior students challenges me to help them refine different theoretical perspectives and skills into an integrated theory that will guide their analysis, design, and development.

The following items are the most compelling evidence for my teaching techniques, (described above) being successful

- The two Faculty Annual Reports for the last two years (2000, 2001): The faculty normally completes the report 
at the end of each year. The head of the department and the Dean view and grade it according to the faculty's academic achievements during that academic year. I had for the last two years on my both reports an excellent grade (above 90\%). The university management normally holds these reports to which the evaluation group of this report can refer.

- The other evidence to my teaching excellence is the letter of support that was written by the head of department of Mathematics and Computer Science at the College of Science (refer to A1.1).

- An additional evidence to my successful teaching techniques is the group of letters that I received from my former students (refer to A1.2).

- You also are welcome to review some of the student evaluation forms I received for the last two years (refer to section of criterion 4).

Course Structure That Supports and Complements My Teaching Techniques

I, strongly support using the E-learning technology as supplement to classroom teaching. In my class session, I attempt to combine lecture presentations with visual demonstrations whenever possible. My courses therefore, are all structured and available on a web server. My primary learning modality is a web-based coordination tool that I supplement with, PowerPoint slides and email.

In each course's web page, I provide students with the course outline that includes several components such as; course description, grading policy, student's grades, weekly assignments, and links to search engines, email, and relevant course materials. I also have, partially used the elearning application WebCt with two courses $\mathrm{C}^{++}$ Programming and Database.

Furthermore, I have taught networking course using the online CCNA CISCO Academy material and application. Every chapter, of CISCO material involves quiz questions expressed as web-based forms, with automation and perfection-based grading. This material is taught totally over the web, and the students get assessed and graded on-line.

When I supervise student on a final year project I apply a student-centered learning method that provides students with problem-solving, self-directed learning, and collaborative learning skills. With this approach students are more involved in, and responsible for, their own learning, working in groups, and taking responsibility for solving professional problems. My role is to create a problem situation for the students and then act as a director and an advisor while the students work out a solution.

Finally, I have to say that the major time-consuming part of my preparation is developing the computer-based tasks, revising them each semester, developing the infrastructure they are based on, and ensuring that the system provides no-excuses reliability and transparency.
This is quite time-consuming to develop and refine because they are both technically and pedagogically complex.

\subsection{Criterion \#2: Curriculum Development}

The rapid evolution of the computing discipline requires an ongoing review of the corresponding curriculum. Given the pace of change in our discipline, the process of updating the computing curriculum on a frequent time space has become highly necessary in order to remain effective. Students are then able to learn concepts and skills that adequately represent the professional setting in which they will be employed.

Computing course curriculum has been for many years one of my strong research areas of my interest. I have been heavily involved in surveying and using standard curricula, such as those produced by joint task forces of ACM/IEEEE, and IS'97. In this area, I have recently published two papers in descent American journals. I also, have been, heavily involved, over many years, on several occasions in developing new computing curriculum, changing curricula and course syllabi processes.

My major contribution in the area of curriculum development, at UAE University may be summarized in the following points;

- Immediately after I was appointed head of the computer science division at the college of science, I submitted to the management a self-assessment report, which outlines my view, and the necessary work that needs to be done on restructuring the curriculum of the computer science degree.

- I was responsible to review the entire curriculum of the computer science at the college of science.

- I then restructured and introduced several courses such as Java, Networking using CCNA material, Operating Systems, (using Microsoft certificate), and Final year project.

- I have essentially contributed to the development of the syllabi of the capstone course.

- Besides being the director of the computer science program at the College of Information Systems (CIT), I was, also appointed as the coordinator of the curriculum committee for the entire college. With the relatively short time being at the CIT I did few changes in the curriculum that are presented the college documents.

\subsection{Criterion \#3: Relevancy Handouts \& Textbooks}

My lectures are designed to be crisp, meaningful, and motivating. Clarity of presentation is crucial. Difficult course concepts must be prudently approached, most often with illustrative examples, and students must be able to gain confidence in their abilities to both master the course material as well as develop higher order levels of insight. Each of my courses contains a required set of detailed lecture notes/handouts, keyed to the presentation modules, which enables students to focus on my lectures with minimal need to expend time copying material into their 
desktops/notebooks. The combination of detailed lecture notes/handouts and presentation graphics modules provides me with the capability to cover, in a more thorough, penetrating and efficacious manner, the subject matter of the course.

For each course I teach I, normally supply lecture notes/handouts and the PowerPoint slides.

As the nature of computer discipline is evolving so rapid, selecting textbooks is a high responsible decision that a computer teacher can make. Being for several years in charge of leading programs of computer science, the decision of selecting or reviewing a list of textbooks for the degree is part of my responsibility.

In order to keep pace with the new development in the computing books I always view websites for many bookshops, authors, and publishers. I regularly arrange meetings between the college faculties and publishing Companies. I also, have contacted very well known authors of books in computing that we teach and were granted the privileges to post their PowerPoint slides and some of their material on the CIT Intranet site for our students to view.

\subsection{Criterion \#4: Student Evaluation}

Continual improvement is a highly important issue for me, both in class and in my life in general. I am always thinking about how my classes can be more effective for my students. One important method for improving my classes is getting student feedback. I found the University process for getting students feedback at the end of each semester an excellent quality assurance activity. Also, I regularly ask my students of what they think regarding my classes and what is effective for them and what is not.

\subsection{Criterion \#5: Course Portfolio}

This section of the portfolio document presents a table that shows the information about the Computer Science courses I taught during the five semesters (between Sept 1999, and June 2001) at the UAE University. The courses involve Java and C++ Programming, Networking, Operating Systems, Database, and senior research projects. The table has several fields, including; the course code and title, number of semesters, number of sections, course $\mathrm{Web} / \mathrm{WebCT}$ information.

Each of the courses, listed in the table, is associated with a course file available in the department.

The content of a course file normally depends on its intended use. Many sources offer various recommendations and categories for designing the portfolio. The following list of components that I normally include within the file/portfolio of each course I teach:

- A list and description of the course I teach

- The course syllabi

- Teaching procedure \& grading Policy

- Student evaluations

- Exams, quizzes, projects
- Instructional materials used in my course (ex, handouts, PowerPoint slides, computer programs, audio/visual materials)

- Copies of the exam papers

- Copies of some students' transcripts

\subsection{Criterion \#6: Offer Short Courses, Conferences,} and Workshops for Teaching Development

The processes of teaching and learning have become part of my life as an educator for the last 17 years. For the five academic semesters I spent at the UAE University, I have been actively contributing to developing the university learning environment. Being at the university, in this relatively short period, I have managed to achieve the following development:

- Initiating the organization of an International Symposium in E-Learning that was held on May, 2002. Being the chairperson of the symposium steering committee I have been actively and intensively contributing to every aspect of it. The symposium has contributed towards developing a much better learning environment for the University.

- Attending and presenting papers in several international conferences concerned with using Computing in education and E-Learning. This part of the portfolio document presents a table that has the fields; conference name, paper title, date and conference location. The conferences involved were held in Florida, South Africa, Cancun, Mexico, and New Jersey.

- Organizing the Student Programming Contest within the UAE University campus, that has contributed in enhancing student-learning ability. Also in encouraging teachers to produce better programming competitors amongst their students

- Delivering several workshops and seminars for the University faculty for using Java and web technology in teaching

- Participating in roundtable discussions and workshops, in E-Learning within UAE

- Running intensive classes in CISCO CCNA Academy for the instructors of the college of science in order to qualify them to run the CISCO lab and to assist faculty teaching networking courses

- Contributing to the National E-Learning competition, "IT Challenge", as a juror

\subsection{Criterion \#7: Teaching Related Publications}

For many years, so far, the education environment has become part of my research and development interest. Through those years, I have been involved in several research projects in Curriculum development and in developing E-Learning applications. Such involvement has resulted in publication of several papers in recognized journals and conference proceedings. This section of the portfolio document presents a table that shows the papers I 
wrote in this regard, the name of journal in which the paper was published, the date of publication.

Finally, I strongly feel that, in the relatively small time I spent at the UAE University, my contribution to teaching, curriculum development, e-learning development, and research in education has been valuable and significant to enhancing the university-learning environment. Moreover, I feel that I put all my previous experience, and did the best I could to contribute to my university and eventually to the UAE society.

I would like, also to take this opportunity to express to the committee responsible of reviewing this report my sincere gratitude for the kind effort and time they will spend in reading my report and review my portfolio.

\section{Conclusion}

The teaching portfolio is an effective tool for improving teaching, in a sense that it can be used as a self- reflective record of a teacher's performance and a tool for teacher's self-evaluation. In addition, many institutions around the world have been recently using a teaching portfolio as an assessment tool for evaluating faculty in formative or summative purposes. In this regard, it has been considered, as a widely accepted means of documenting teaching effectiveness when applying for academic positions, awards, promotion, or tenure.
In this article, the author presents his teaching portfolio that was submitted for the faculty distinction award in teaching at UAE University in United Arab Emirates for the year 2002. The portfolio, in this case was introduced as an example model for using a faculty's teaching portfolio as a convenient way of documenting evidence on teaching quality and effectiveness when applying for summative evaluation purposes.

In this study, in addition to the benefit of using the teaching portfolio for summative purposes, several other benefits that may also yield when building your portfolio. One benefit is that the teaching portfolio can emphasize the teachers' ability to instruct students effectively, by providing a textured picture of teaching and learning as they unfold over time and across different contexts. Furthermore, teachers can examine, discuss, reflect on their performance, and review their activities, strategies, and plans for the future.

One should also observe that the process of creating and using a teaching portfolio is a privately exercised discipline. It enables individual teachers to archive their records and distil them for presentation as evidence at the decision points in their individual careers. Furthermore, this process can give rise to fresh concepts of teaching and learning in general; fresh perceptions of the specific processes of teaching and learning that occur in their own classes; reason to experiment, innovate, and undertake action research into their own teaching.

\section{References}

[1] Centra, J. A. (1994). The use of the teaching portfolio and student evaluations for summative evaluation. Journal of Higher Education, 65, (5), 555-570.

[2] Murray, J. P. (1995). The teaching portfolio: A tool for department chairpersons to create a climate of teaching excellence. Innovative Higher Education, 19, 163-175.

[3] Ross, D. D., Bondy, E., Hartle, L., Lamme, L. L. \& Webb, R. B. (1995). Guidelines for portfolio preparation: Implications from an analysis of teaching portfolios at the University of Florida. Innovative Higher Education, 20, (1), 45-62.

[4] Advisory Center for University Education, University of Adelaide. (No date). Evaluation service: teaching portfolios.[On-line], February 21, 1997. Available HTTP: http://wwwetu.itd.adelaide.edu.au/ACUE/acue/AE/teach_portfolios.html

[5] Cerbin, W. (1994). The course portfolio as a tool for continuous improvement of teaching and learning. Journal on Excellence in College Teaching, 5, (1), 95-105.

\section{Get Connected with Computing History Visit the IEEE History Center and Virtual Museum at} www.ieee.org/museum 